University of Nebraska - Lincoln

DigitalCommons@University of Nebraska - Lincoln

Daugherty Water for Food Global Institute:

Faculty Publications

Daugherty Water for Food Global Institute

$4-29-2020$

\title{
Sediment Outflow under Simulated Rainfall Conditions with Varying Geotechnical Properties
}

Pranjay Joshi

Akhilesh Kumar

P. V. Singh

Jahangeer Jahangeer

Follow this and additional works at: https://digitalcommons.unl.edu/wffdocs

Part of the Environmental Health and Protection Commons, Environmental Monitoring Commons, Hydraulic Engineering Commons, Hydrology Commons, Natural Resource Economics Commons, Natural Resources and Conservation Commons, Natural Resources Management and Policy Commons, Sustainability Commons, and the Water Resource Management Commons

This Article is brought to you for free and open access by the Daugherty Water for Food Global Institute at DigitalCommons@University of Nebraska - Lincoln. It has been accepted for inclusion in Daugherty Water for Food Global Institute: Faculty Publications by an authorized administrator of DigitalCommons@University of Nebraska Lincoln. 


\title{
Sediment Outflow under Simulated Rainfall Conditions with Varying Geotechnical Properties
}

\author{
Pranjay Joshi, ${ }^{1}$ Akhilesh Kumar, ${ }^{2}$ P. V. Singh, ${ }^{3}$ \\ and Jahangeer Jahangeer, A.M. ASCE ${ }^{4}$
}

\begin{abstract}
1 Postgraduate Student, G. B. Pant University of Agriculture and Technology, Pantnagar, Uttarakhnad 263145, India.Email: pranjayjoshi@gmail.com 2 Professor, G. B. Pant University of Agriculture and Technology, Pantnagar, Uttarakhnad 263145, India. Email: akhilesh.pantnagar@gmail.com 3 Junior Research Officer, G. B. Pant University of Agriculture and Technology, Pantnagar, Uttarakhnad 263145, India. Email: er.pvsingh@gmail.com 4 Postdoctoral Research Associate, Nebraska Water Center, University of Nebraska-Lincoln, 2021 Transformation Dr., Ste. 3220 P.O. Box 886204, Lincoln, NE 68588-6204. (Corresponding author). ORCID: $\underline{\text { https://orcid. }}$ org/0000-0002-5070-1265. Email: jahangeer@unl.edu
\end{abstract}

\begin{abstract}
The vulnerability of soil toward erosion might be reduced by having a good vegetative cover over the soil surface, slope improvement, and improving soil properties so that it is not easily detached and transported. However, the establishment of proper vegetative cover is a long process because it takes time for seeds to germinate and attain maturity. As an alternative approach, if soil resistance was increased by increasing the shear strength of soil against erosive forces offered by eroding agents, the soil system would become capable of withstanding the detachment of its particles on the
\end{abstract}

Published in Journal of Hazardous, Toxic, and Radioactive Waste 24:3 (July 2020), No. 04020022, 13 pp.

Copyright (C) 2020 ASCE. Used by permission. DOI: 10.1061/(ASCE)HZ.2153-5515.0000513.

Submitted September 9, 2019; approved January 2, 2020; published April 29, 2020. 
application of shear stress. To achieve the desired strength, jute fiber and guar gum were added $(0.3 \%, 0.5 \%$, and $0.7 \%)$ to a test plot of $1 \mathrm{~m}^{2}$ area which resulted in three different trays of three different strengths. The strength parameters were determined with the help of a triaxial test where unconsolidated undrained (UU) conditions were maintained throughout the experiment. The tray was maintained at different slopes $(4 \%, 6 \%, 8 \%, 10 \%$, and $12 \%)$ under a rainfall simulator of $1 \mathrm{~m}^{2}$ area that was capable of producing rainfall intensity of 12.8 and $17.5 \mathrm{~cm} / \mathrm{h}$. The sediment outflow for a particular tray at different rainfall intensity and the slope were collected and measured. The recorded observations revealed that the value of the shear strength of soil increased as a result of the applied treatments and the soil loss rate/sediment outflow rate decreased for every combination of land slope and rainfall intensity. In addition, it was found that for a particular value of cohesion and angle of internal friction, the runoff rate increased with rainfall intensity for every land slope and the sediment concentration and sediment outflow rate increased with rainfall intensity as well as land slope. The results of this study will be useful for measuring soil loss, sediment runoff, and sediment discharged from farmland taking into account the properties of rainfall, soil, and flow.

Keywords: soil erosion, rainfall simulator, rainfall intensity, sediment outflow

\section{Introduction}

Soil erosion and sediment outflow processes are composed of the detachment and transportation of detached soil particles (Issa et al. 2006; Vaezi et al. 2017). The occurrence and magnitude of both of these processes depend on a large number of variables and, therefore, become complex (Helming et al. 2002; Mohamadi and Kavian 2015). The erosive potential of the erosive agent and the vulnerability of the erodible soil system primarily influenced the soil particle detachment process (Ellison 1948). This detachment caused soil loss and was responsible for dryness, productivity loss, deterioration of soil structure, and many other properties of soil (Lal 2001, 2003; Li et al. 2013). When these detached particles were transported from one place to another, they started to disturb their surrounding systems depending on their composition. The detachment took place through excess rainfall when the flow of water became concentrated and applied a drag force to the soil surface. The drag force overcame the resistance offered by the soil particles when they started to detach and moved from the soil system and became displaced.

This detachment could be from cultivated land which contained ample amounts of chemicals such as pesticides and fertilizers or from a highway construction site, which yielded 10 times more detachment 
than cultivated land, 200 times that of grassland, and 2,000 times that of forest land under similar conditions (Jahangeer and Kumar 2013; Liu et al. 1999). When these particles were transported, they increased the sediment load that led to pollution in their respective medium (Jahangeer et al. 2017; Rügner et al. 2019). For example, when displaced particles were mixed in the air, they caused air pollution. Similarly, when these fragments entered a waterbody, they caused an imbalance in the system which could be physical, chemical, or biological. Particles that remained in suspension increased the turbidity in the water, serving as a medium for different organic or inorganic matters to stick onto them, that created a breeding ground for microorganisms such as bacteria and viruses to grow and thrive in, therefore, spreading diseases (WHO 2008; Liu et al. 2019).

When these particles became aggraded in the bed they increased the bed level causing the water level to rise in the waterbody (Higson and Singer 2015). In the case of a reservoir, this aggradation caused a reduction in the storage volume of the reservoir which adversely affected the overall utility of the reservoir regarding irrigation potential, flood and drought mitigation, and hydroelectric power generation (Kondolf et al. 2014; Annandale 2006). For a turbine, the pumping of these sediment particles caused severe damage to blades and other moving parts (Thapa et al. 2012; Ghiban et al. 2017). The sediment generation and transportation process in a watershed area was a very complex phenomenon because they involved a large number of variables related to watershed characteristics including soil type and morphology, vegetative cover conditions including cropping systems and level of supporting management practices apart from parameters related to rainfall and runoff (Helming et al. 2002).

To overcome these problems, the primary solution lay in the control of excessive sediment outflow from erosion prone areas. This was achieved by adopting appropriate soil conservation measures to improve the susceptibility of soil system toward erosion under the impact of the erosive potential of rainfall and runoff. This was achieved by having an excellent vegetative cover over the soil surface, slope improvement, and improving soil properties so that it was not easily detached and transported (Martin 1940).

However, the establishment of proper vegetative cover takes time because it takes time for a seed to germinate and attain maturity. Until the establishment of adequate vegetative cover, there were chances of loss 
of soil depending on the magnitude of the erosivity of the erosive agents and the erodibility of the eroding soil system. As an alternative approach, if soil resistance was increased by increasing the mechanical strength of soil against erosive force offered by an eroding agent, the soil system would become capable of withstanding the detachment of its particles upon the application of shear stress (Liu et al. 2019). Using this practice, an additive was mixed to the soil which increased the mechanical strength of the soil. The additives ranged from biodegradable to nonbiodegradable or partially biodegradable inert materials.

A study was conducted to ascertain the effects of the addition of binder with fiber on the mechanical behavior of soft soil (Correia et al. 2015). It was observed that the addition of fiber in smaller quantities to the stabilized soft soil resulted in a reduction of stiffness, compressive and direct tensile strength, a decrease in the loss of strength after the peak, and a change in performance from fragile to more ductile. In addition, it was stated that the effect of the fibers was significant, but in the direct tensile strength tests, the addition of fibers had an insignificant effect. Relationships between the compressive and observed tensile strength were developed in this study (Li et al. 2014). They observed the tensile behavior of soil when the soil was reinforced with discrete fibers. The effect of fiber content, dry density, and water content on the tensile strength of soil was studied. It was observed that a minimal amount of fiber was required to show enhancement in the tensile strength, an increased dosage from $0 \%$ to $0.2 \%$ increased tensile strength by $65.7 \%$. Moreover, it changed the brittle tensile failure of the soil to ductile tensile failure and this technique proved to be a favorable ground improvement technique. With the increase in the dry density of soil, the tensile strength of soil increased as it increased the contact area of soil and fiber. In addition, it was observed that with the increase in water content the tensile strength of soil decreased as the bond between soil and fiber became weak. Cruse and Larson (1977), tested their hypothesis on the relation of soil splash from the raindrop impact to soil shear strength with the help of a rainfall simulator height $177 \mathrm{~cm}$ and a droplet size of $4.8 \mathrm{~mm}$. For this purpose, they altered the soil composition in three different ways. First, by altering direct solid to solid contact, second, by changing solid to liquid contact, and third by providing a direct bonding mechanism between soil particles. This was achieved by changing bulk density, changing matrix potential, and adding polyvinyl alcohol. 
The soil detached was correlated with the shear strength of soil by a triaxial compression test. Ranjan et al. (1996) conducted a study based on a statistical analysis of the compression test results and studied the effect of fiber properties, soil characteristics, and confining stress on the strength. performance of randomly. dispersed fiber-reinforcement soil. Synthetic and natural fibers were used at $0 \%, 1 \%, 2 \%, 3 \%$, and $4 \%$ fiber content as reinforcement in cohesionless soil. They observed that the shear strength of the randomly distributed fiber-reinforced soil was based on fiber weight fraction, aspect ratio, surface friction, soil character, and its density and confining stress. It was seen that by increasing the percentage of fiber content up to $2 \%$ the shear strength increased. It was also observed that a smaller grain size provided a better contact area and more friction between sand grains and fiber.

Based on the previously mentioned background in this study, two biodegradable additives, jute fiber, and guar gum, were used for stabilization against soil erosion. Jute is a natural organic fiber that is also ecofriendly. It was widely used in combination with vegetation to control erosion of exposed soil (Kalibová et al. 2016). Jute fiber was available in two different varieties woven and nonwoven and possessed a high degree of flexibility with a small percentage of elongation at break. Jute is used today in various other fields such as flood embankments, construction of pavements, and hydraulic structures (Basu et al. 2019; Ghosh et al. 2017). It has a high moisture absorption capacity which made it an ideal choice for increasing the moisture holding capacity of the soil. Guar gum is a polymer that is sticky and has a water holding potential. It is a natural biodegradable inert product (Sharma et al. 2018) that made it an ideal additive to a soil system. The most important property of guar gum is its ability to hydrate rapidly in cold water to attain uniform and very high viscosity at relatively low concentrations.

Ziadat and Taimeh (2013) observed that most climate change studies predicted an increase in the number of extreme events such as heavy rainfall especially in the dry regions, causing increased runoff leading to soil erosion. Bearing this in mind appropriate protection measures were essential for protecting and reducing the susceptibility of the soil. The objective of this study was to study the response of antecedent moisture, land use, slope, and rainfall intensity on runoff and soil erosion. For this purpose, 12 different sites from the Al-Muwaqqar watershed, Jordan were chosen to represent 6 different slope angles ranging from 
$1 \%, 2 \%, 3 \%, 5 \%, 7 \%$, and $9 \%$. A rotating disk rainfall simulator was used to create rainfall intensities of 3,5 , and $10 \mathrm{~mm} / \mathrm{h}$, these intensities in combination with 3 different moisture conditions (dry, wet, and very wet) were used to carry out the research. The results from the regression analysis indicated that rainfall intensity was the primary parameter that affected soil erosion.

Davidová et al. (2016) demonstrated the effect of vegetation cover on surface runoff generation and soil loss using a field rainfall simulator. The results of 15 experiments for oats and wheat crops were presented. The vegetation development was described by the canopy cover and the leaf area index. It was observed that the soil loss decreased significantly from a maximum value of $74.7 \mathrm{~g} / \mathrm{min}$ for oats $(38.4 \mathrm{~g} / \mathrm{min}$ for wheat) to $0.4 \mathrm{~g} / \mathrm{min}(1.5 \mathrm{~g} / \mathrm{min}$ respectively) from the experimental plot of $16 \mathrm{~m}^{2}$ with growing vegetation. It was concluded that canopy development had a positive effect on soil loss reduction, but the effect of the developing cover on the surface runoff generation was not significant.

Das et al. (2016) studied the shear strength parameter of the unreinforced and reinforced soil with coir fiber. A set of direct shear tests were conducted at a normal stress of $0.5,1.0$, and $1.5 \mathrm{~kg} / \mathrm{cm}^{2}$. The coir fiber was added at the rate of $1 \%, 2 \%$, and $3 \%$ by weight of soil. It was observed that the application of coir fiber on sand increased the shear strength parameter that was the angle of internal friction. The main causes of the improved shear strength were that in the absence of reinforcement the soil showed brittle failure, but after the reinforcement, the soil started to show ductile failure because friction had developed between the soil and the reinforced material. In addition, it was observed that increased shear strength parameter was only up to the optimum value of the fiber content, which was $2.1 \%$ beyond this reduction in the internal friction angle was obtained and hence reduction in the shear strength of the soil.

Rainfall was a basic fundamental input into most hydrologic processes specifically in the case of runoff generated sediments (Kumar 2017). Because rain is a naturally occurring phenomenon, which makes it a randomly occurring event, or an unpredictable phenomenon regarding its parameters such as intensity uniformity, duration, and drop size. Because these parameters are beyond human control, it became challenging to find two similar rainstorms that occurred at the required location at the required time. Because of these constraints, it was almost impossible to conduct studies such as rainfall-runoff-sediment yield under 
natural rainfall conditions. An alternate approach, to overcome the previously mentioned constraints, was to carry out these studies under artificially generated rainfall which could be manually regulated to match natural rainfall. Therefore, a small $1 \times 1 \mathrm{~m}^{2}$ size rainfall simulation unit was designed, developed, and calibrated for its rainfall generation capabilities to conduct this study. The test plots of similar size mounted on a slope adjusting mechanism were also developed for this purpose. The exhaustive experiments were conducted using different combinations of input variables to fulfill the objectives of the study.

The main objectives of the study were to include the design and development of a portable rainfall simulation unit to generate simulated rainfall and to observe and compare sediment outflow for different soils under simulated rainfall conditions. The sediment outflow rates were observed to assess the effects of these parameters. When rainfall occurred, the water drop introduced stress over the soil surface. This stress was responsible for the erosion from the soil surface and resulted in sediment generation. The amount of detached soil particles depended on the raindrop size, intensity of rainfall, slope, and the strength of the soil surface. This study highlighted these factors and demonstrated the relation between them. The strength of soil could be quantified with shear strength, which was a sum of cohesion and normal stress. This study highlighted the use of cohesion and angle of internal friction as a parameter to calculate sediment generated from a plot under different intensities of rainfall and slope. The benefit of these experiments was to eliminate the use of portable rainfall simulators at field sites which required a lot of manual work. In the proposed methodology, we collected site specific soil samples and calculated their strength parameters, the shear strength, and the sediment generated at that strength. The study had a wide application to measure the sediment generated at different cohesion and angle of internal friction in the laboratory and generated a database for different shear parameters and slope which could be used for calculating sediment generated from the soil.

\section{Materials and Methods}

The soil material for the laboratory experiments was obtained from the Beni area of Pantnagar, U.S. Nagar (Uttarakhand, India). The procedure described in IS 2720 (Part IV)-1985 was used for the fine grain size 

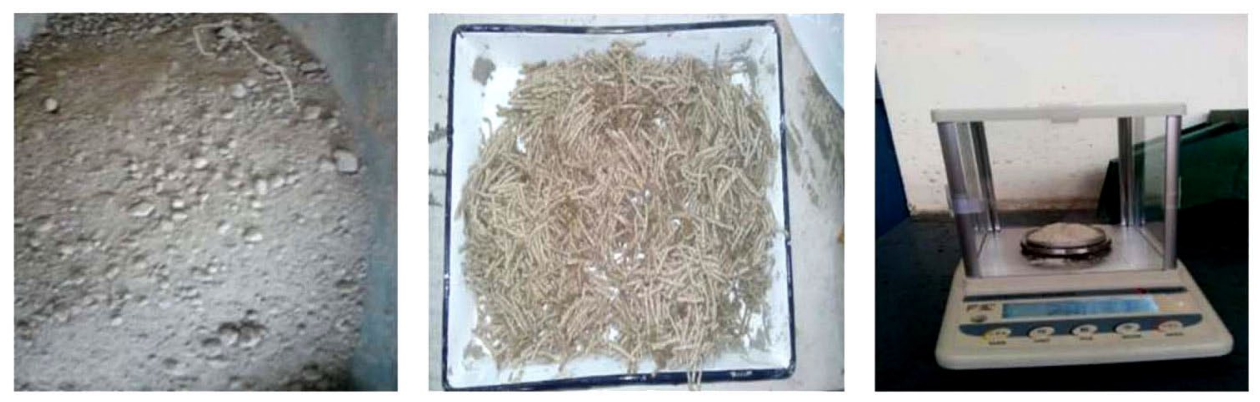

Fig. 1. Soil sample, jute fiber, and guar gum with weighing balance.

distribution of the soil used in the experiment. The relative composition of used soil materials was gravel 4.75 , sand 73 , silt 16.65 , and clay $5.59 \%$ content. The plastic limit, liquid limit, and shrinkage limit played an essential role in soil identification and classification. The study was conducted according to IS 2720 (Part V)-1985. The values of these consistency limits were obtained as liquid limit $\left(w_{L}\right) 22.49$, plastic limit $\left(w_{P}\right)$ 18.82, shrinkage limit $\left(w_{S}\right) 7.59$, and plasticity index $\left(I_{P}\right) 3.67 \%$. Based on these observations, the soil was classified as ML-OL according to IS 1498 (1970). For the experimental test, the method 2720 (Part-III)-1980 was performed according to IS. The average value of specific gravity for the soil of 3 samples obtained was 2.52 .

To attain the desired soil strength values (cohesion, angle of internal friction) 2 additives were used in different concentrations, that is, $0.3 \%$ jute fiber and $0.3 \%$ guar gum, $0.5 \%$ jute fiber and $0.5 \%$ guar gum, and $0.7 \%$ jute fiber and $0.7 \%$ guar gum. All the concentrations were taken by weight/weight ratio.

The jute fibers of $40 \mathrm{~mm}$ length (Fig. 1) were used in this study as a reinforcement material. The jute was obtained from the local market of Pantnagar. This fiber was generally available as a thread. Jute fiber was abundantly used to reinforce soil to make it more resistant to erosion by changing its properties. It was available at a very low cost and could be easily mixed with soil. Jute fiber is chemically inert and can absorb moisture.

Guar gum is one of the outstanding representatives of the new generation of plant gums (Fig. 1). It is an inert and biodegradable material that does not create any harmful effects when mixed with soil. It was extracted from a plant called guar which was available throughout the year 

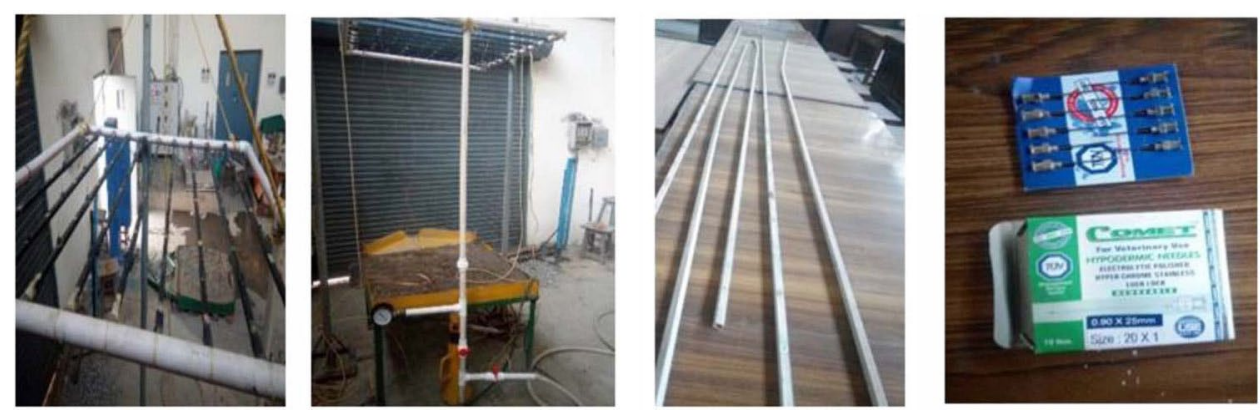

Fig. 2. Simulation system with lateral aluminum pipes and hypodermic needles.

and is drought resistant. It is primarily the endosperm of guar beans. Seeds gums were important agrochemicals and were used in various industries worldwide. Guar gum being sticky was suspected of having high cohesion which when used in the soil could increase cohesion between soil particles.

The rainfall generation unit of $1 \times 1 \mathrm{~m}^{2}$ size was fabricated using lightweight PVC pipes and was mainly responsible for the generation of rainfall. The rainfall was generated by using hypodermic needles (Comet Needles, India) mounted on the PVC pipes vertically upward with predefined spacing. Rigid circular PVC pipes of $25 \mathrm{~mm}$ diameter were used to design the mainframe of the simulation system to make it lightweight. An outer frame of $100 \times 100 \mathrm{~cm}^{2}$ size was first made so that water supplied by the pump through the delivery pipe circulated through the entire frame. The two adjacent outer frame pipes were drilled to make circular openings at $10 \mathrm{~cm}$ intervals connected with aluminum lateral pipes. The pipes were connected with an elbow which increased the end to end distance by $3 \mathrm{~cm}$ which made the area of simulator unit 1.06 $\times 1.06 \mathrm{~m}^{2}$. The elbow joint and the pipe were connected using a strong adhesive to make all connections leak proof and to provide sufficient strength to these connections.

Lightweight square aluminum pipes $10 \times 10 \mathrm{~mm}^{2}$ (Fig. 2) were used as laterals to mount the hypodermic needles (Comet Needles). The space of these pipes was taken square to facilitate the mounting of the hypodermic needles properly. These pipes were strong enough to sustain high pressure. In total, 9 square aluminum pipes $17 \mathrm{~m}$ in length were used for supplying water in the lateral direction. Openings of $1 \mathrm{~mm}$ diameter were created by drilling these pipes in the midsurface at $20 \mathrm{~cm}$ 
intervals to fix the hypodermic needles so that the water jets could develop through the hypodermic needles. These square aluminum pipes were connected with an outer PVC pipe frame using a flexible connector. The joints were made watertight using an adhesive firmly around the aluminum pipe. The circular cross section pipe was hard and was inserted $0.5 \mathrm{~cm}$ inside the PVC pipe to make the joint rigid and strong.

The rainfall generation unit consisted of $20 \mathrm{G}$ hypodermic needles approximately $4 \mathrm{~cm}$ in length with a square metal base of $0.5 \mathrm{~cm}$. The hypodermic needles were mounted using a strong sealing gum to make them leakproof over the PVC pipes. A total of 45 needles were used in the system with spacing of $10 \times 20 \mathrm{~cm}^{2}$. To fix the needles accurately in an upward vertical direction, a thin wire was inserted inside the needles and a hole in the aluminum pipe and at the base of the needle, an adhesive (Araldite) was used to fix them. When the needles were settled an additional thick layer of adhesive was used to ensure that the needles did not leak from the base. When this layer had settled a layer of m-seal (Pidilite Industries Ltd., India) was used so that the needles had sufficient resistance against the force exerted by the jet.

The pressure the water was supplied to the rainfall generation unit controlled the rainfall parameters. The pressure gauge of diameter 10 $\mathrm{cm}$ was mounted onto the main supply pipe. The range of this gauge was $0-2.1 \mathrm{~kg} / \mathrm{cm}^{2}$. In this study, water was supplied at two pressures 0.4 and $0.5 \mathrm{~kg} / \mathrm{cm}^{2}$.

The rainfall generation unit was supported on a circular and angle welded metallic frame. The base of this supporting system up to a height of $2.5 \mathrm{~m}$ was a circular section, and the top $2.5 \mathrm{~m}$ was a welded angle section. The structure was fastened onto the floor surface using fasteners. The concrete surface was drilled, and fasteners were inserted using a hammer and stand. This was carried out to ensure that during operation, the entire system remained firm and did not vibrate. Because the simulation unit was fixed at the base, the mounting process was easier because the stands were more stable. At the top of the stands, a pulley was welded with the help of flat plates. Through these pulleys, $12 \mathrm{~m}$ of nylon rope was inserted and connected to the sides of the simulator unit which was lifted manually to the desired height. The height of the stand was maintained at $5 \mathrm{~m}$, and the simulation unit was suspended at $4.5 \mathrm{~m}$.

A monoblock single-phase electric operated $1 / 2$ HP centrifugal pump was used to supply water to the simulation unit, through a supply line. 


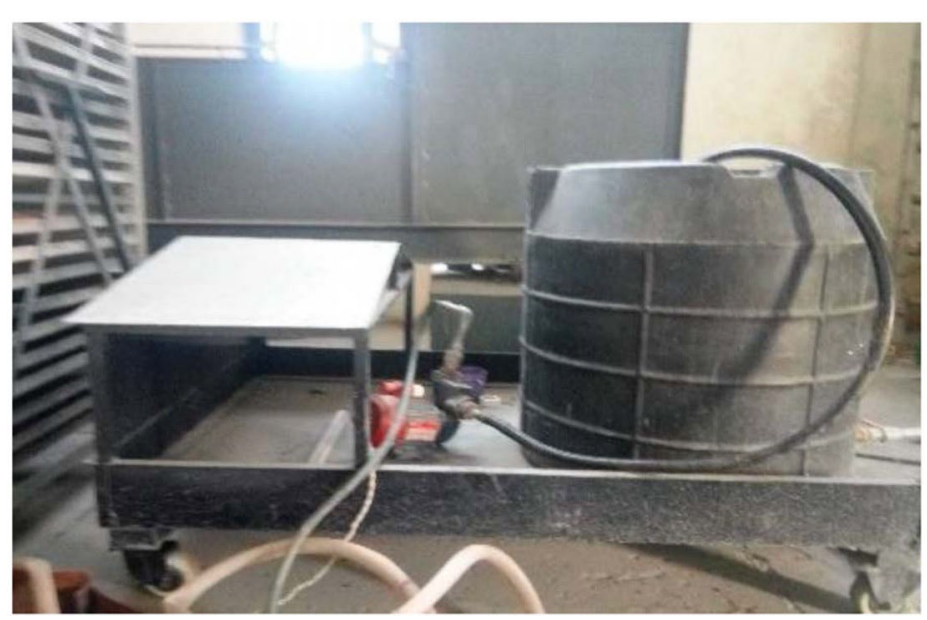

Fig. 3. Trolley arrangement with centrifugal pump and storage tank.

This pump received water from a water source in the laboratory. The water supply line consisted of a suction pipe and a delivery pipe. The suction pipe was a rigid pipe to prevent choking due to a vacuum that developed at the suction end and the delivery pipe was a flexible PVC pipe that was connected to the output of the centrifugal pump and conveyed water to the simulation system.

To control flow two $25 \mathrm{~mm}$ size plastic valves were used. One valve was fitted near the pressure gage and another was fitted to the bypass line. These valves helped to maintain constant pressure so that a uniform rate of flow was supplied to the rainfall generation unit and the rainfall parameters remained uniform.

The water source consisted of a $275 \mathrm{~L}$ water tank on a moving trolley (Fig. 3). The tank was filled with water before the experiments through a direct water supply line from the main water supply using a flexible PVC pipe. To ensure that only clean water was supplied to the rainfall generation unit the water was held stagnant for few hours so that silt particles if any, settled down and did not block the needles.

\section{Methodologies Adopted for the Experimental Study}

Various methodologies adopted in the calibration of the experimental setup, conducting the experiments, taking observations, and the data analysis are explained in the following sections. 


\section{Calibration of the Rainfall Generation Unit}

The developed rainfall generation unit was calibrated to ascertain its rainfall generation capability and to determine rainfall parameters at varying pressures that water was supplied to it. For this purpose, rainfall intensity, uniformity coefficient, and raindrop size were determined at a particular setting of the simulation unit.

The rainfall intensity and uniformity coefficient were determined by collecting the amount of rainfall over a specified duration in 4 catch cans of $11 \mathrm{~cm}$ diameter placed at different locations under the simulation unit. The raindrop size was determined by using the flour method. The following relationships were used to determine rainfall intensity and uniformity coefficient. Rainfall intensity was calculated using the following formula:

$$
I_{a}=\left[\sum_{i=1}^{N}\left(\frac{V_{i}}{A_{i}}\right) / N \times 60 / t\right]
$$

where $I_{a}=$ average intensity of simulated rainfall, $\mathrm{cm} / \mathrm{h} ; V_{i}=$ volume of water collected in the $i$ th catch can in $5 \mathrm{~min}, \mathrm{~cm}_{3} ; A_{i}=$ cross-sectional area of the ith catch can, $\mathrm{cm}_{2}$; and $N=$ total number of cans used.

The uniformity coefficient which described how uniformly the generated rainfall was distributed over the entire plot area was determined using the following relationship given by Christiansen (1942):

$$
U_{c}=\left[1-\sum_{i=1}^{N}\left|X_{i}\right| / M N\right] \times 100
$$

where $U_{c}=$ uniformity coefficient, $\% ; X_{i}=$ deviation of the depth of water collected in $i$ th can from the mean depth, $\mathrm{cm} ; M=$ mean value of depth of water collected in all the catch cans, $\mathrm{cm}$; and $N=$ total number of catch cans used.

In this study, all the catch cans used were of the same crosssectional area and, therefore, the previous equation can be expressed as

$$
U_{c}=\left[1-\sum_{i=1}^{N}\left|V_{i}\right| / V N\right] \times 100
$$




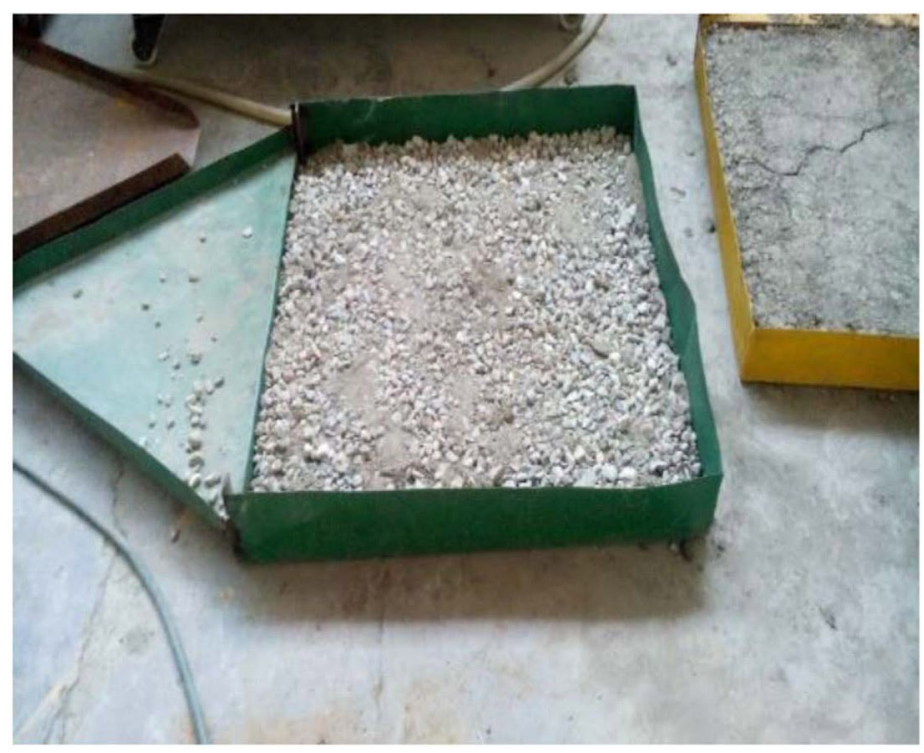

Fig. 4. Test plot.

where $V_{i}=$ deviation of the volume of water collected in the $i$ th catch can from the mean volume, $\mathrm{cm}^{3}$; and $V=$ mean value of the volume of water collected in $N$ catch can, $\mathrm{cm}^{3}$.

\section{Sediment Outflow for Different Shear Parameters Under Simulated Rainfall Conditions}

This stage involved the study of sediment outflow under simulated rainfall on a plot size of $1 \times 1 \mathrm{~m}^{2}$. The sediment outflow for varying conditions of rainfall was analyzed with different shear parameters of the soil.

\section{Test Plot}

To conduct experiments under laboratory conditions, 3 square plots $1 \times 1 \mathrm{~m}^{2}$ size and $12 \mathrm{~cm}$ deep were fabricated in the university workshop using a mild iron sheet. The plots (Fig. 4) were supported on the metallic strong square stand approximately $54 \mathrm{~cm}$ height. A total of 9 openings of $1 \mathrm{~cm}$ in diameter were made at the base of the plot so that water percolating through soil could drain from the plot. The plots were painted with acrylic paints to prevent corrosion. 
Preparation of Test Plots

The fabricated plots $1 \times 1 \mathrm{~m}^{2}$ were used as test plots to conduct sediment outflow studies. First, a $2 \mathrm{~cm}$ layer of aggregates of different sizes was provided at the base of the test plot. Then a thin layer of coarse sand approximately $1 \mathrm{~cm}$ thickness was provided to create a natural filter for soil particles that allowed percolated water to drain from the soil. The plot was filled to a height of $10 \mathrm{~cm}$ with saturated soil selected for conducting experiments. The soil in the plot was mixed with two additives, that is, guar gum and jute fiber at $0.3 \%, 0.5 \%, 0.7 \%$ concentration (by weight), to achieve the desired cohesion and angle of internal friction value. The cohesion and angle of internal friction value were calculated after performing the unconsolidated undrained (UU) triaxial test on soils of test plots with different percentages of additives according to IS: 2720 (Part XI)-1993. Care was taken to maintain the uniform procedure throughout the study.

\section{Slope Adjustments}

Two $1 \mathrm{t}$ capacity jacks were used to provide the required slope to the plot by tilting the plot using the jacks. One jack was installed at the front of the plots stand and another at the back. The front jack was raised slightly so that all the load which was transmitted when the back jacks were lifted was safely transferred without causing harm to support the frame (Fig. 5). For slope measurement, the scale was used to measure the height at the front and back. The difference in the height was used to determine the slope at that particular tilt. Five different slopes were analyzed, for example, 4\%, 6\%, 8\%, 10\%, and 12\%.

\section{Rainfall Generation}

The rainfall was produced with the help of the developed portable rainfall simulator under controlled conditions in the laboratory to conduct sediment outflow studies for different combinations of rainfall parameters, land slope, and soil treatments. For this purpose, 2 rainfall intensities of 12.7 and $17.5 \mathrm{~cm} / \mathrm{h}$ were created to study sediment outflow. To create these intensities, the water was supplied to the rainfall generation unit at $0.4 \mathrm{~kg} / \mathrm{cm}^{2}$ to create a rainfall intensity of $12.7 \mathrm{~cm} / \mathrm{h}$ and 0.5 $\mathrm{kg} / \mathrm{cm}^{2}$ pressure to create a rainfall intensity of $17.5 \mathrm{~cm} / \mathrm{h}$, respectively. 

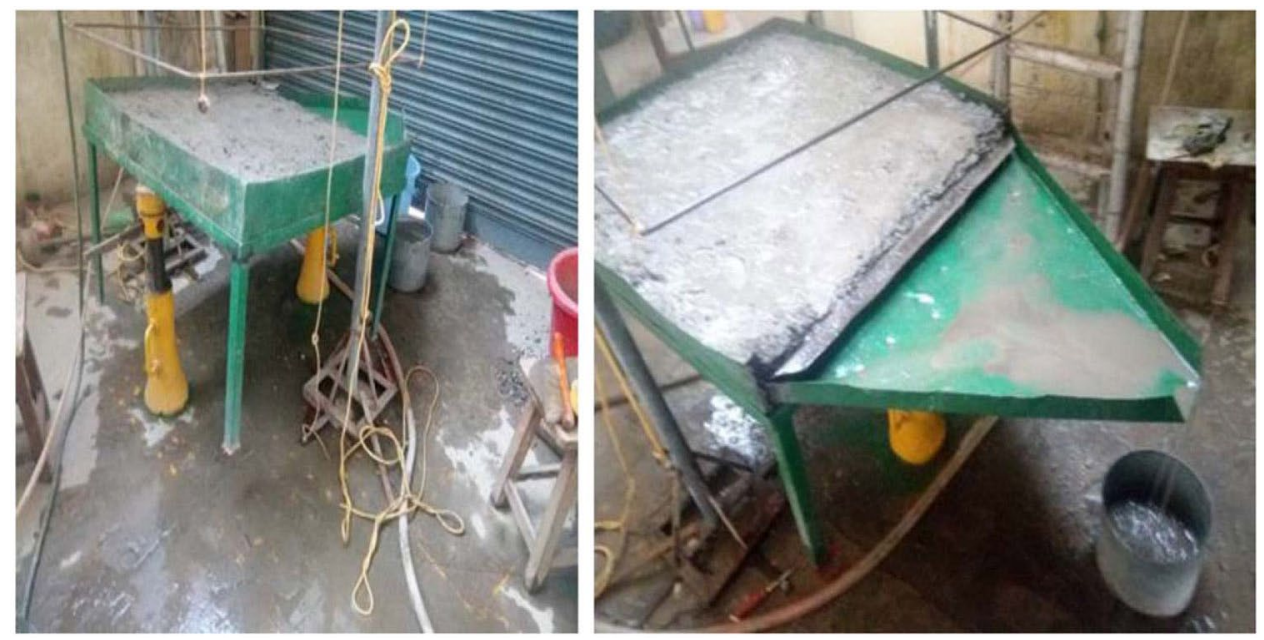

Fig. 5. Sediment outflow measurement.

\section{Sediment Outflow Measurement}

Once the entire setup was ready, the rainfall was produced using the developed portable rainfall simulator and the runoff volume was collected in a collection tank (Fig. 5). The collected runoff was stirred, and a sediment sample of $100 \mathrm{~cm}^{3}$ was obtained in a glass beaker. The collected runoff samples were analyzed for sediment concentration using the following oven drying method for a particular set of variables. The sample was then transferred to an aluminum container. The sample was weighed with a precision weighing balance with $1 \mathrm{mg}$ accuracy. The weighed sample was placed in the oven for $24 \mathrm{~h}$ at $80^{\circ} \mathrm{C}$ to dry the sample. Each time the procedure was repeated to obtain sediment outflow rates that were correlated with different variables involved in this study.

\section{Result and Discussions}

\section{Development and Calibration of Portable Rainfall Simulation System}

To observe sediment outflow for varying soil properties that resulted from the treatment of soil with additives a small size portable rainfall simulation system was developed in the laboratory that was $5 \mathrm{~m}$ in height. The simulator was calibrated for its rainfall generation 
Table 1. Determination of simulated rainfall parameters at selected pressures

\begin{tabular}{|c|c|c|c|c|c|c|c|c|c|}
\hline \multirow[b]{3}{*}{ Pressure } & \multirow{3}{*}{$\begin{array}{l}\text { Collectors } \\
\text { position }\end{array}$} & \multirow{2}{*}{\multicolumn{5}{|c|}{ Volume of rainfall collected (c.c.) }} & \multicolumn{3}{|c|}{ Rainfall parameters } \\
\hline & & & & & & & \multirow{2}{*}{$\begin{array}{c}\text { Rainfall } \\
\text { intensity }(\mathrm{cm} / \mathrm{h})\end{array}$} & \multirow{2}{*}{$\begin{array}{c}\text { Uniformity } \\
\text { coefficient (\%) }\end{array}$} & \multirow{2}{*}{$\begin{array}{l}\text { Raindrop } \\
\text { size }(\mathrm{mm})\end{array}$} \\
\hline & & $V_{1}$ & $V_{2}$ & $V_{3}$ & $V_{4}$ & $V_{\text {avg }}$ & & & \\
\hline \multirow[t]{4}{*}{$0.4 \mathrm{~kg} / \mathrm{cm}^{2}$} & $\mathrm{~A}_{1}$ & 95 & 100 & 110 & 100 & 101.25 & \multirow[t]{4}{*}{12.8} & \multirow[t]{4}{*}{100.0} & \multirow[t]{4}{*}{2.5} \\
\hline & $\mathrm{A}_{2}$ & 110 & 95 & 110 & 95 & 102.51 & & & \\
\hline & $\mathrm{A}_{3}$ & 105 & 100 & 115 & 100 & 105.00 & & & \\
\hline & $\mathrm{A}_{4}$ & 100 & 95 & 100 & 90 & 96.25 & & & \\
\hline \multirow[t]{4}{*}{$0.5 \mathrm{~kg} / \mathrm{cm}^{2}$} & $A_{1}$ & 150 & 150 & 150 & 150 & 150.00 & \multirow[t]{4}{*}{17.5} & \multirow[t]{4}{*}{99.78} & \multirow[t]{4}{*}{2.9} \\
\hline & $\mathrm{A}_{2}$ & 130 & 150 & 140 & 140 & 140.00 & & & \\
\hline & $\mathrm{A}_{3}$ & 150 & 150 & 140 & 140 & 145.00 & & & \\
\hline & $\mathrm{A}_{4}$ & 125 & 125 & 125 & 135 & 127.50 & & & \\
\hline
\end{tabular}

capabilities that mimicked natural rainfall conditions. The simulation system was free from any disturbance because it was rigidly tightened on all four sides. The calibration of this system was carried out in terms of the pressure at which water was supplied to the rainfall generation unit to produce rainfall. The intensity, uniformity, and other characteristics of simulated rainfall were dependent on the pressure of water. In this study, water was supplied at 2 pressures, 0.4 and $0.5 \mathrm{~kg} / \mathrm{cm}^{2}$, and the rainfall parameters were observed according to the procedure outlined in the materials and methods. It was observed that at $0.4 \mathrm{~kg} / \mathrm{cm}^{2}$ pressure, the rainfall intensity of $12.8 \mathrm{~cm} / \mathrm{h}$ was obtained (Table 1) which occurred almost uniformly over the entire test plot giving a uniform coefficient of $>99 \%$ and a rainfall droplet size of $2.5 \mathrm{~mm}$. Similarly, at 0.5 $\mathrm{kg} / \mathrm{cm}^{2}$ water pressure, a rainfall intensity of $17.5 \mathrm{~cm} / \mathrm{h}$ was obtained (Table 1) with a uniform distribution of $99.78 \%$ and a rainfall droplet size of $2.9 \mathrm{~mm}$. To verify these observations and to overcome any errors in measurement, several trials were performed and average values were obtained that were used to conduct further experiments.

\section{Observed Sediment Outflow from Soil with Different Shear Parameters at Selected Slopes and Rainfall Intensities}

Soil erosion in terms of sediment outflow was observed with the varying shear strength of soil obtained as a result of soil treatments. For this, the test plot filled with soil that had different shear strength parameters was used in this study. In the case of sheet erosion, the shear strength 
played an important role and, therefore, shear strength parameters were used to determine the effect of the applied soil treatment for this study. The shear strength parameters which were considered in the analysis were cohesion and angle of internal friction. The sediment outflow was observed for particular values of shear parameters for all selected values of land slope and intensity of rainfall. For conducting experiments, the soil with three different shear parameters was used for different combinations of land slope and rainfall intensities. In this study, it was carried out for 2 rainfall intensities and 5 land slopes. With 3 types of soil, the total number of combinations was $3 \times 2 \times 5=30$ and the experiment for sediment outflow observation was performed 30 times. Every trial was run for $5 \mathrm{~min}$ for rainfall intensities of 12.8 and $17.5 \mathrm{~cm} / \mathrm{h}$. The runoff generated from the plot was collected in a bucket and 100 $\mathrm{cm}^{3}$ of the representative sample was collected from it for further analysis of sediment concentration by following the oven drying method. To obtain accuracy in observations, several trials were performed and an average value was obtained. The details of the results are described in the following sections.

\section{Observed Sediment Outflow for Soil Having a Cohesion of $0.12 \mathrm{~kg} / \mathrm{cm}^{2}$ and Angle of Internal Friction $6.0^{\circ}$ at Selected Land Slopes and Rainfall Intensities}

To observe the effect of rainfall over a soil of cohesiveness $0.12 \mathrm{~kg} /$ $\mathrm{cm}^{2}$ and angle of internal friction $5.99^{\circ}$, which was achieved at $0.3 \%$ jute fiber and $0.3 \%$ gaur gum, the soil was subjected to 2 rainfall intensities. One was $17.5 \mathrm{~cm} / \mathrm{h}$ and the second was $12.8 \mathrm{~cm} / \mathrm{h}$. These 2 rainfall intensities were applied for $5 \mathrm{~min}$ over the soil at 4\%, 6\%, 8\%, 10\%, and $12 \%$ slope. When rainfall at a rate of $17.5 \mathrm{~cm} / \mathrm{h}$ was applied to a $4 \%$ land slope for $5 \mathrm{~min}$ it resulted in the sediment concentration of 6,255 ppm. The runoff was generated at a rate of $2,614.05 \mathrm{~cm}^{3} / \mathrm{min} / \mathrm{m}^{2}$ which resulted in the sediment outflow rate of $16.35 \mathrm{~g} / \mathrm{min} / \mathrm{m}^{2}$. Similarly, when a $6 \%$ slope was considered the runoff samples collected had 834 and 835 mg of sediment in $100 \mathrm{~cm}^{3}$ of the sample that gave a sediment concentration of 8,360 ppm. When the total volume of runoff generated remained the same for a given intensity, the sediment outflow rate was $21.85 \mathrm{~g} /$ $\mathrm{min} / \mathrm{m}^{2}$. With this rainfall intensity at $8 \%$ land slope, the sediment concentration was 10,430 ppm and the sediment outflow rate observed was 
Table 2. Observed sediment outflow at selected land slopes for soil having a cohesion of $0.12 \mathrm{~kg} / \mathrm{cm}^{2}$ and angle of internal friction $6^{\circ}$ and rainfall intensities of $17.5 \mathrm{~cm} / \mathrm{h}$

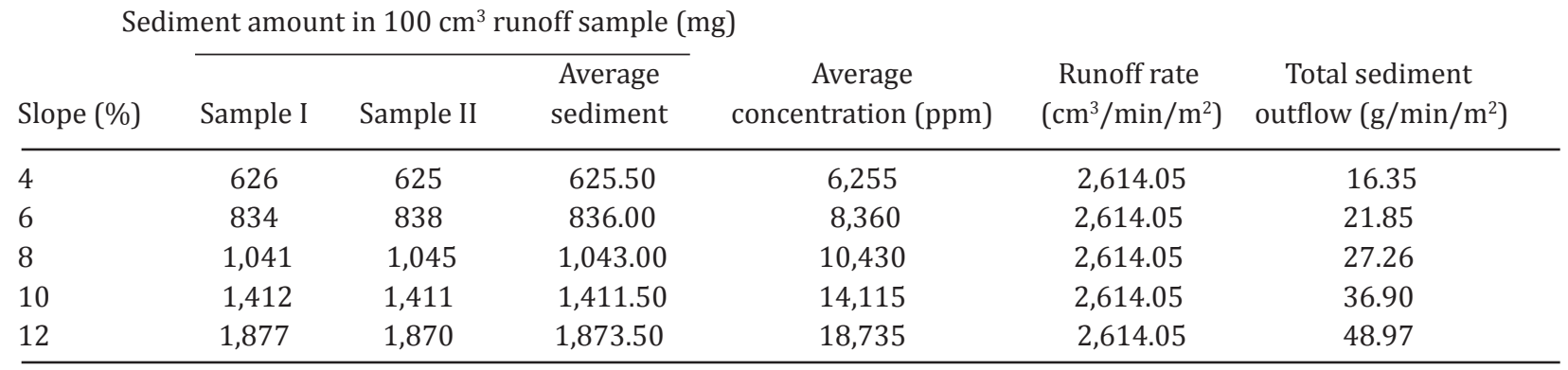

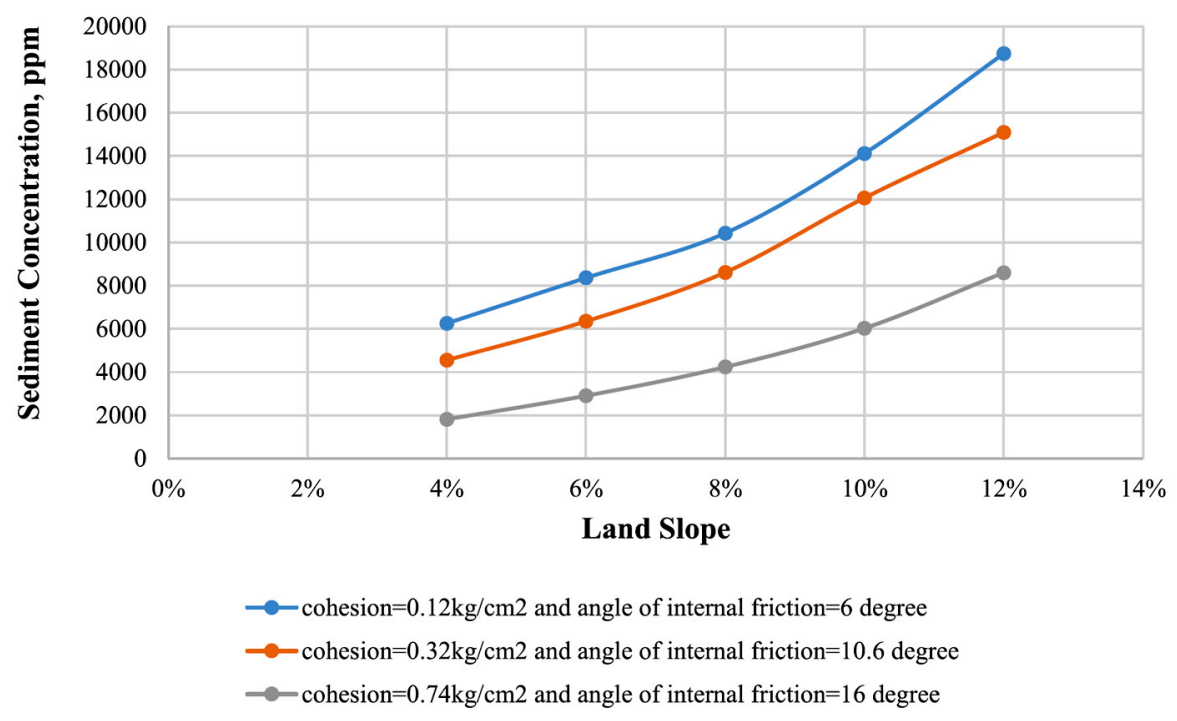

Fig. 6. Sediment outflow for different soil strength of 5 slopes at $17.52 \mathrm{~cm} / \mathrm{h}$ rainfall intensity.

$27.26 \mathrm{~g} / \mathrm{min} / \mathrm{m}^{2}$. The sediment concentration was increased to 14,115 and $18,735 \mathrm{ppm}$ when the land slope was increased to $10 \%$ and $12 \%$ with a respective rate of sediment outflow of 36.90 and $48.97 \mathrm{~g} / \mathrm{min} /$ $\mathrm{m}^{2}$ respectively. The observations are given in Table 2 and are shown graphically in Fig. 6.

Similarly, when rainfall at a rate of $12.8 \mathrm{~cm} / \mathrm{h}$ was applied to all selected land slopes, it produced an average runoff rate of $1,978.2 \mathrm{~cm}^{3}$ / $\mathrm{min} / \mathrm{m}^{2}$, however, with a different rate of sediment concentration, the sediment outflow rates were found to be different for varying land slopes. At 4\% land slope the sediment concentration was 5,215 ppm 
Table 3. Observed sediment outflow at selected land slopes for soil having a cohesion of $0.12 \mathrm{~kg} / \mathrm{cm}^{2}$ and angle of internal friction $6^{\circ}$ and rainfall intensities of $12.8 \mathrm{~cm} / \mathrm{h}$

\begin{tabular}{|c|c|c|c|c|c|c|}
\hline Slope (\%) & Sample I & Sample II & $\begin{array}{l}\text { Average } \\
\text { sediment }\end{array}$ & $\begin{array}{c}\text { Average } \\
\text { concentration }(\mathrm{ppm})\end{array}$ & $\begin{array}{c}\text { Runoff rate } \\
\left(\mathrm{cm}^{3} / \mathrm{min} / \mathrm{m}^{2}\right)\end{array}$ & $\begin{array}{c}\text { Total sediment } \\
\text { outflow }\left(\mathrm{g} / \mathrm{min} / \mathrm{m}^{2}\right)\end{array}$ \\
\hline 4 & 524 & 519 & 521.50 & 5,215 & $1,978.2$ & 10.32 \\
\hline 6 & 670 & 672 & 671.00 & 6,710 & $1,978.2$ & 13.27 \\
\hline 8 & 912 & 918 & 915.00 & 9,150 & $1,978.2$ & 18.10 \\
\hline 10 & 1,331 & 1,226 & $1,278.50$ & 12,785 & $1,978.2$ & 25.29 \\
\hline 12 & 1,747 & 1,742 & $1,744.50$ & 17,445 & $1,978.2$ & 34.51 \\
\hline
\end{tabular}
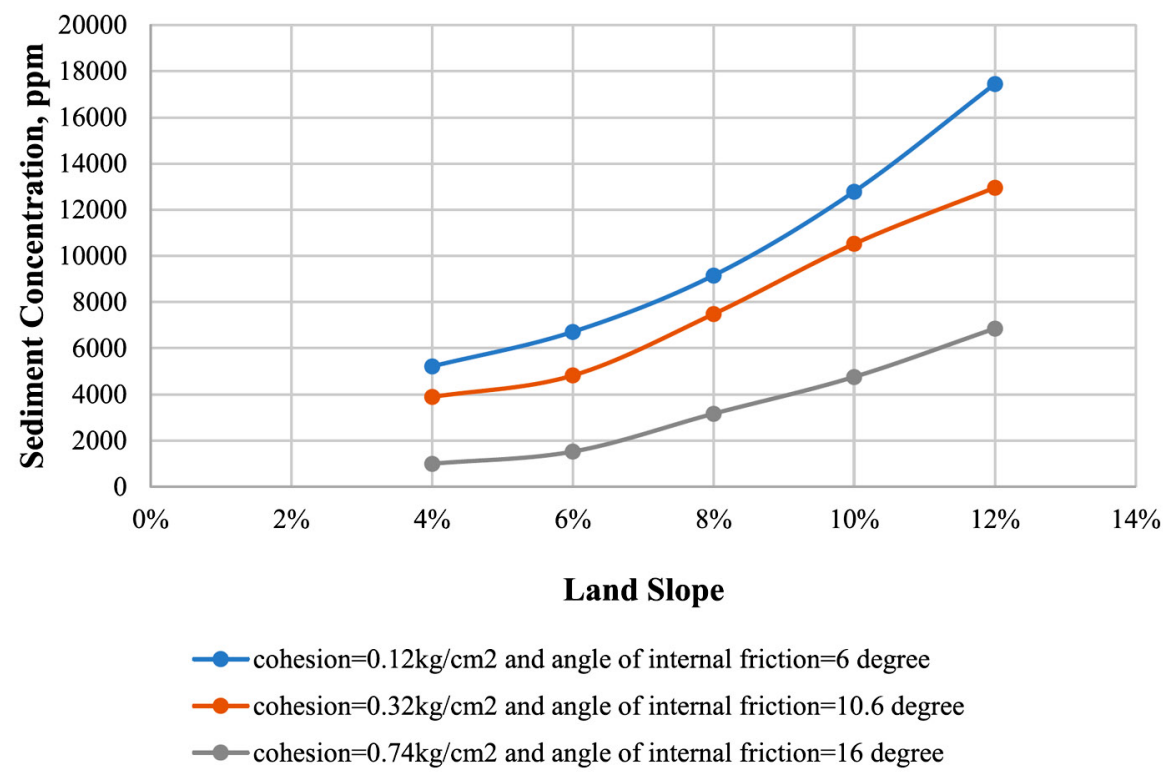

Fig. 7. Sediment outflow for different soil strength of 5 slopes at $12.8 \mathrm{~cm} / \mathrm{h}$ rainfall intensity.

which increased to $17,445 \mathrm{ppm}$ for $12 \%$ land slope with corresponding sediment outflow rates of 10.32 and $34.51 \mathrm{~g} / \mathrm{min} / \mathrm{m}^{2}$. At $6 \%$ of land slope, the sediment concentration was $6,710 \mathrm{ppm}$ with a corresponding sediment outflow rate of $13.27 \mathrm{~g} / \mathrm{min} / \mathrm{m}^{2}$. At $8 \%$ land slope the sediment concentration was $9,150 \mathrm{ppm}$ which increased to $12,785 \mathrm{ppm}$ for $10 \%$ land slope with corresponding sediment outflow rates of 18.10 and $25.29 \mathrm{~g} / \mathrm{min} / \mathrm{m}^{2}$ respectively. In this case, the findings indicated that the sediment concentration increased with increasing rainfall intensity as well as with the increase in land slope for a treatment. The observations are given in Table $\mathbf{3}$ and are shown graphically in Fig. $\mathbf{7 .}$ 
Table 4. Observed sediment outflow at selected land slopes for soil having a cohesion of $0.32 \mathrm{~kg} / \mathrm{cm}_{2}$ and angle of internal friction $10.6^{\circ}$ with rainfall intensities of $17.5 \mathrm{~cm} / \mathrm{h}$

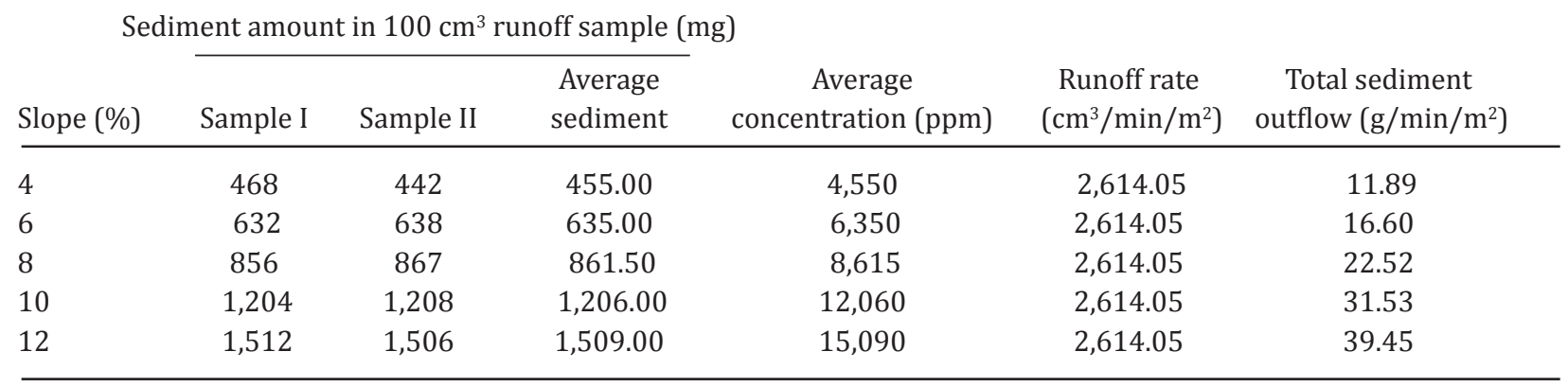

\section{Observed Sediment Outflow for Soil Having a Cohesion of $0.32 \mathrm{~kg} / \mathrm{cm}^{2}$ and Angle of Internal Friction $10.6^{\circ}$ at Selected Land Slopes and Rainfall Intensities}

The observations of the runoff rate, sediment concentration, and sediment outflow rate recorded to study the effect of rainfall over a soil of cohesiveness $0.32 \mathrm{~kg} / \mathrm{cm}^{2}$ and angle of internal friction $10.6^{\circ}$, which was achieved at $0.5 \%$ jute fiber and $0.5 \%$ gaur gum, are provided in Table 4 for rainfall intensity of $17.5 \mathrm{~cm} / \mathrm{h}$. It was observed that when rainfall at a rate of $17.5 \mathrm{~cm} / \mathrm{h}$ was applied it resulted in the same rate of runoff of $2,614.05 \mathrm{~cm}^{3} / \mathrm{min} / \mathrm{m}^{2}$ for all selected slopes. At $4 \%$ land slope for $5 \mathrm{~min}$, this rainfall resulted in the sediment concentration of 4,550 ppm which resulted in the sediment outflow rate of $11.89 \mathrm{~g} / \mathrm{min} / \mathrm{m}^{2}$. Similarly, when a $6 \%$ slope was considered the sediment concentration was $6,350 \mathrm{ppm}$ and the total volume of runoff generated remained the same for a given intensity, the sediment outflow rate was $16.60 \mathrm{~g} / \mathrm{min} / \mathrm{m}^{2}$. With this rainfall intensity at an $8 \%$ land slope, the sediment concentration was 8,615 $\mathrm{ppm}$ and the sediment outflow rate observed was $22.52 \mathrm{~g} / \mathrm{min} / \mathrm{m}^{2}$. The sediment concentration increased to 12,060 and $15,090 \mathrm{ppm}$ when the land slope was increased to $10 \%$ and $12 \%$ with a respective rate of sediment outflow of 31.53 and $39.45 \mathrm{~g} / \mathrm{min} / \mathrm{m}^{2}$, respectively. The variation is shown graphically in Fig. 6.

Similarly, when rainfall at a rate of $12.8 \mathrm{~cm} / \mathrm{h}$ was applied to all selected land slopes, it produced an average runoff rate of $1,978.2 \mathrm{~cm}^{3}$ / $\mathrm{min} / \mathrm{m}^{2}$, however, with a different rate of sediment concentration, the sediment outflow rates were different for varying land slopes. At $4 \%$ 
Table 5. Observed sediment outflow at selected land slopes for soil having a cohesion of $0.32 \mathrm{~kg} / \mathrm{cm} 2$ and angle of internal friction $10.6^{\circ}$ with rainfall intensities of $12.8 \mathrm{~cm} / \mathrm{h}$

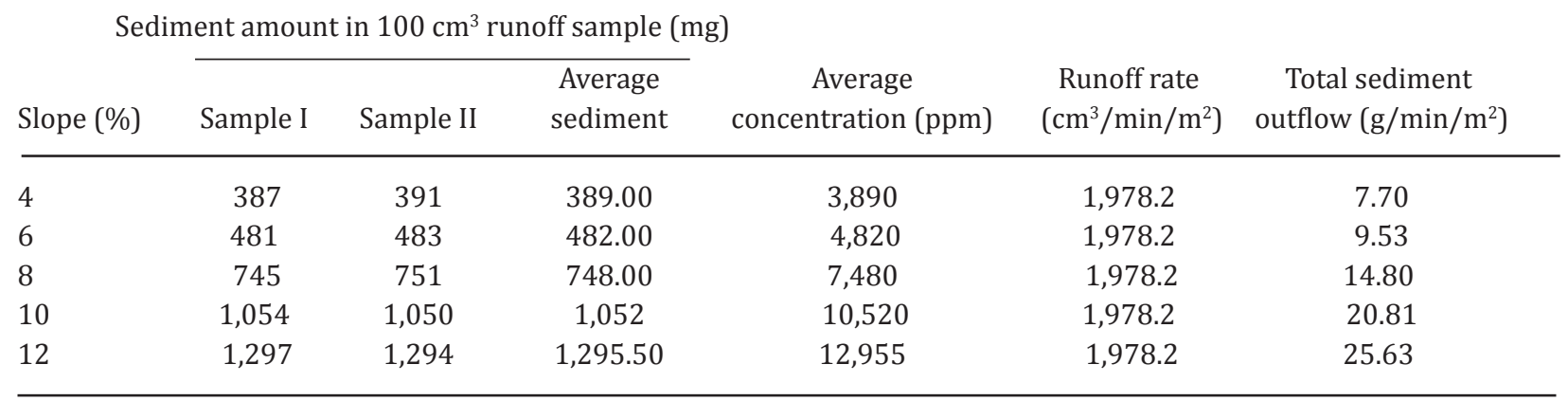

land slope the sediment concentration was 3,890 ppm which increased to $12,955 \mathrm{ppm}$ for $12 \%$ land slope with corresponding sediment outflow rates of 7.7 and $25.63 \mathrm{~g} / \mathrm{min} / \mathrm{m}^{2}$. At $6 \%$ land slope the sediment concentration was $4,820 \mathrm{ppm}$ with a corresponding sediment outflow rate of $9.53 \mathrm{~g} / \mathrm{min} / \mathrm{m}^{2}$. At $8 \%$ land slope, the sediment concentration was 7,480 ppm which increased to 10,520 ppm for $10 \%$ land slope with corresponding sediment outflow rates of 14.80 and $20.81 \mathrm{~g} / \mathrm{min} / \mathrm{m}^{2}$, respectively. The previous findings indicated that the sediment concentration increased with increasing rainfall intensity as well as with the increase in land slope for a treatment. The observations are given in Table $\mathbf{5}$ and variation in sediment outflow graphically is shown in Fig. 7.

\section{Observed Sediment Outflow for Soil Having a Cohesion of $0.74 \mathrm{~kg} /$ $\mathrm{cm}^{2}$ and Angle of Internal Friction $16^{\circ}$ at Selected Land Slopes and Rainfall Intensities}

It was observed that when rainfall at a rate of $17.5 \mathrm{~cm} / \mathrm{h}$ was applied, it resulted in the same rate of runoff of $2,614.05 \mathrm{~cm}^{3} / \mathrm{min} / \mathrm{m}^{2}$ at all selected slopes, which was similar to the previous results. In this case, it was found that at $4 \%$ land slope the sediment concentration of 1,815 ppm resulted in a sediment outflow rate of $4.74 \mathrm{~g} / \mathrm{min} / \mathrm{m}^{2}$. Similarly, at $6 \%$ land slope, the sediment concentration was $2,905 \mathrm{ppm}$ and the total volume of runoff generated remained the same for a given intensity, the sediment outflow rate was $7.59 \mathrm{~g} / \mathrm{min} / \mathrm{m}^{2}$.With this rainfall intensity at $8 \%$ land slope, the sediment concentration was $4,235 \mathrm{ppm}$ and the sediment outflow rate was $11.07 \mathrm{~g} / \mathrm{min} / \mathrm{m}^{2}$. The sediment concentration 
Table 6. Observed sediment outflow at selected land slopes for soil having a cohesion of $0.74 \mathrm{~kg} / \mathrm{cm} 2$ and angle of internal friction $16^{\circ}$ with rainfall intensities of $17.5 \mathrm{~cm} / \mathrm{h}$

\begin{tabular}{|c|c|c|c|c|c|c|}
\hline \multirow[b]{2}{*}{ Slope (\%) } & \multicolumn{6}{|c|}{ diment amount in $100 \mathrm{~cm}^{3}$ runoff sample (mg) } \\
\hline & Sample I & Sample II & $\begin{array}{c}\text { Average } \\
\text { sediment }\end{array}$ & $\begin{array}{c}\text { Average } \\
\text { concentration (ppm) }\end{array}$ & $\begin{array}{c}\text { Runoff rate } \\
\left(\mathrm{cm}^{3} / \mathrm{min} / \mathrm{m}^{2}\right)\end{array}$ & $\begin{array}{c}\text { Total sediment } \\
\text { outflow }\left(\mathrm{g} / \mathrm{min} / \mathrm{m}^{2}\right)\end{array}$ \\
\hline 4 & 180 & 183 & 181.50 & 1,815 & $2,614.05$ & 4.74 \\
\hline 6 & 288 & 293 & 290.50 & 2,905 & $2,614.05$ & 7.59 \\
\hline 8 & 421 & 426 & 423.50 & 4,235 & $2,614.05$ & 11.07 \\
\hline 10 & 598 & 607 & 602.50 & 6,025 & $2,614.05$ & 15.75 \\
\hline 12 & 856 & 864 & 860.00 & 8,600 & $2,614.05$ & 22.48 \\
\hline
\end{tabular}

Table 7. Observed sediment outflow at selected land slopes for soil having a cohesion of $0.74 \mathrm{~kg} / \mathrm{cm} 2$ and angle of internal friction $16^{\circ}$ with rainfall intensities of $12.8 \mathrm{~cm} / \mathrm{h}$

\begin{tabular}{|c|c|c|c|c|c|c|}
\hline \multirow[b]{2}{*}{ Slope (\%) } & \multicolumn{6}{|c|}{ diment amount in $100 \mathrm{~cm}^{3}$ runoff sample (mg) } \\
\hline & Sample I & Sample II & $\begin{array}{l}\text { Average } \\
\text { sediment }\end{array}$ & $\begin{array}{c}\text { Average } \\
\text { concentration (ppm) }\end{array}$ & $\begin{array}{c}\text { Runoff rate } \\
\left(\mathrm{cm}^{3} / \mathrm{min} / \mathrm{m}^{2}\right)\end{array}$ & $\begin{array}{c}\text { Total sediment } \\
\text { outflow }\left(\mathrm{g} / \mathrm{min} / \mathrm{m}^{2}\right)\end{array}$ \\
\hline 4 & 101 & 99 & 100.00 & 1,000 & $1,978.2$ & 1.98 \\
\hline 6 & 151 & 154 & 152.50 & 1,525 & $1,978.2$ & 3.02 \\
\hline 8 & 314 & 319 & 316.50 & 3,165 & $1,978.2$ & 6.26 \\
\hline 10 & 472 & 480 & 476.00 & 4,760 & $1,978.2$ & 9.42 \\
\hline 12 & 684 & 687 & 685.50 & 6,855 & $1,978.2$ & 13.56 \\
\hline
\end{tabular}

increased to 6,025 and 8,600 ppm when the land slope was increased to $10 \%$ and $12 \%$ with a respective rate of sediment outflow of 15.75 and $22.48 \mathrm{~g} / \mathrm{min} / \mathrm{m}^{2}$ respectively for a rainfall intensity of $17.5 \mathrm{~cm} / \mathrm{h}$. The observations of the runoff rate, sediment concentration, and sediment outflow rate recorded to study the effect of rainfall over the soil with a cohesiveness $0.74 \mathrm{~kg} / \mathrm{cm}^{2}$ and angle of internal friction $16^{\circ}$, which was achieved at $0.7 \%$ jute fiber and $0.7 \%$ gaur gum, are provided in Table 6 and graphically shown in Fig. 6 for a rainfall intensity of $17.5 \mathrm{~cm} / \mathrm{h}$.

The observed sediment outflow data were recorded and provided in Table 7 and Fig. 7 for a rainfall intensity of $12.8 \mathrm{~cm} / \mathrm{h}$. It was revealed from the observations that when rainfall at a rate of $12.8 \mathrm{~cm} / \mathrm{h}$ was applied to all selected land slopes, it produced an average runoff rate of $1,978.2 \mathrm{~cm}^{3} / \mathrm{min} / \mathrm{m}^{2}$, however, with a different rate of sediment concentration, the sediment outflow rates were different for varying land slopes. At 4\% land slope the sediment concentration was 1,000 ppm 
which increased to $6,855 \mathrm{ppm}$ for $12 \%$ land slope with corresponding sediment outflow rates of 1.98 and $13.56 \mathrm{~g} / \mathrm{min} / \mathrm{m}^{2}$. At $6 \%$ land slope the sediment concentration was $1,525 \mathrm{ppm}$ with corresponding sediment outflow rate of $3.02 \mathrm{~g} / \mathrm{min} / \mathrm{m}^{2}$. At $8 \%$ land slope the sediment concentration was $3,165 \mathrm{ppm}$ which increased to $4,760 \mathrm{ppm}$ for $10 \%$ land slope with corresponding sediment outflow rates of 6.26 and 9.42 $\mathrm{g} / \mathrm{min} / \mathrm{m}^{2}$, respectively. The previous findings indicated that the sediment concentration increased with increasing rainfall intensity as well as with the increase in land slope for a treatment.

Analysis of the trend of the recorded observations revealed that for a particular value of cohesive strength and angle of internal friction of soil, which together represented its shear strength (cohesive strength and angle of internal friction), had a significant impact on soil erosion for all combinations of land slope and rainfall intensity. In addition, it was found that for a particular value of cohesion and angle of internal friction, the runoff rate increased with rainfall intensity for every land slope while the sediment concentration and sediment outflow rate increased with rainfall intensity as well as land slope.

\section{Observed Sediment Concentration for a Particular Value of Cohe- sion and Angle of Internal Friction for Selected Land Slope and Rainfall Intensities}

The observed sediment outflow data were analyzed for a particular value of cohesion and angle of internal friction to determine how rainfall and land slope were affecting sediment outflow for a given condition of cohesion and angle of internal friction. It was found that for the cohesion of $0.12 \mathrm{~kg} / \mathrm{cm}^{2}$ and angle of internal friction $6.0^{\circ}$ (Fig. 8) at $4 \%$ land slope the sediment concentration was $6,255 \mathrm{ppm}$ for $17.5 \mathrm{~cm} / \mathrm{h}$ rainfall intensity and 5,215 ppm for $12.8 \mathrm{~cm} / \mathrm{h}$ rainfall intensity. The highest sediment concentrations of 18,735 and $17,445 \mathrm{ppm}$ were found at $12 \%$ land slope for 17.5 and $12.8 \mathrm{~cm} / \mathrm{h}$ rainfall intensity respectively. Similarly, for the cohesion of $0.32 \mathrm{~kg} / \mathrm{cm}^{2}$ and angle of internal friction $10.6^{\circ}$ (Fig. 9), the sediment concentration was increased for higher intensities of rainfall and the reduction in sediment concentration was almost in a similar pattern. As explained previously, the maximum sediment concentration was achieved at $12 \%$ land slope and the minimum was at $4 \%$ land slope both for 17.5 and $12.8 \mathrm{~cm} / \mathrm{h}$ rainfall intensities. In the case of cohesion 


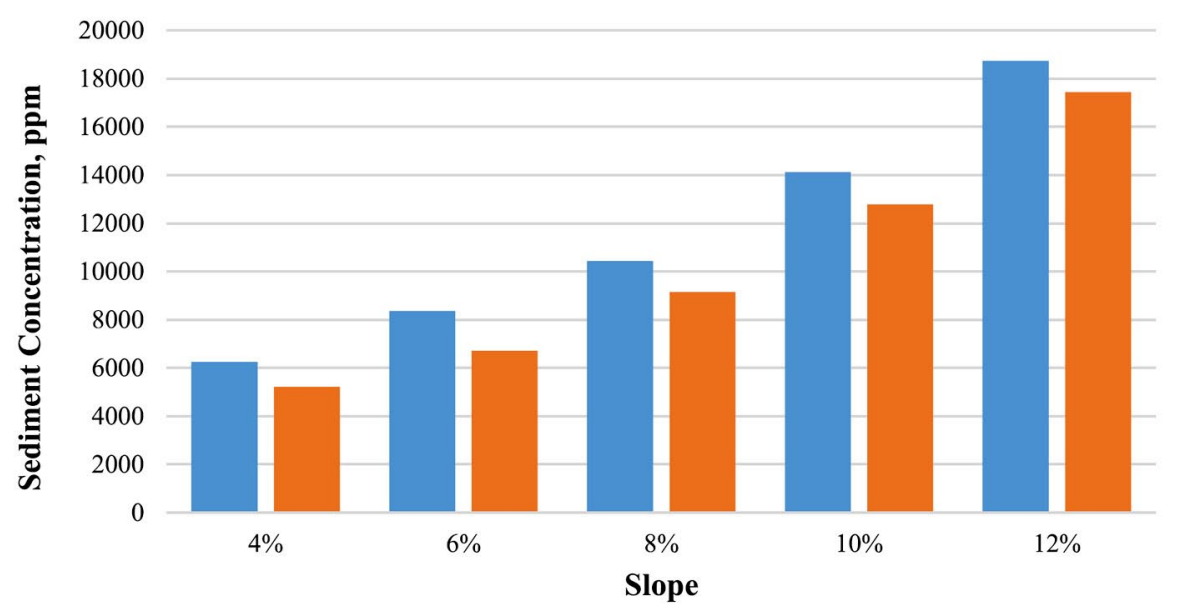

Rainfall Intensity $=12.8 \mathrm{~cm} / \mathrm{h} \quad$ Rainfall Intensity $=17.5 \mathrm{~cm} / \mathrm{h}$

Fig. 8. Observed sediment concentration for cohesion $0.12 \mathrm{~kg} / \mathrm{cm} 2$ and angle of internal friction $6.0^{\circ}$ and different slope and rainfall intensities.

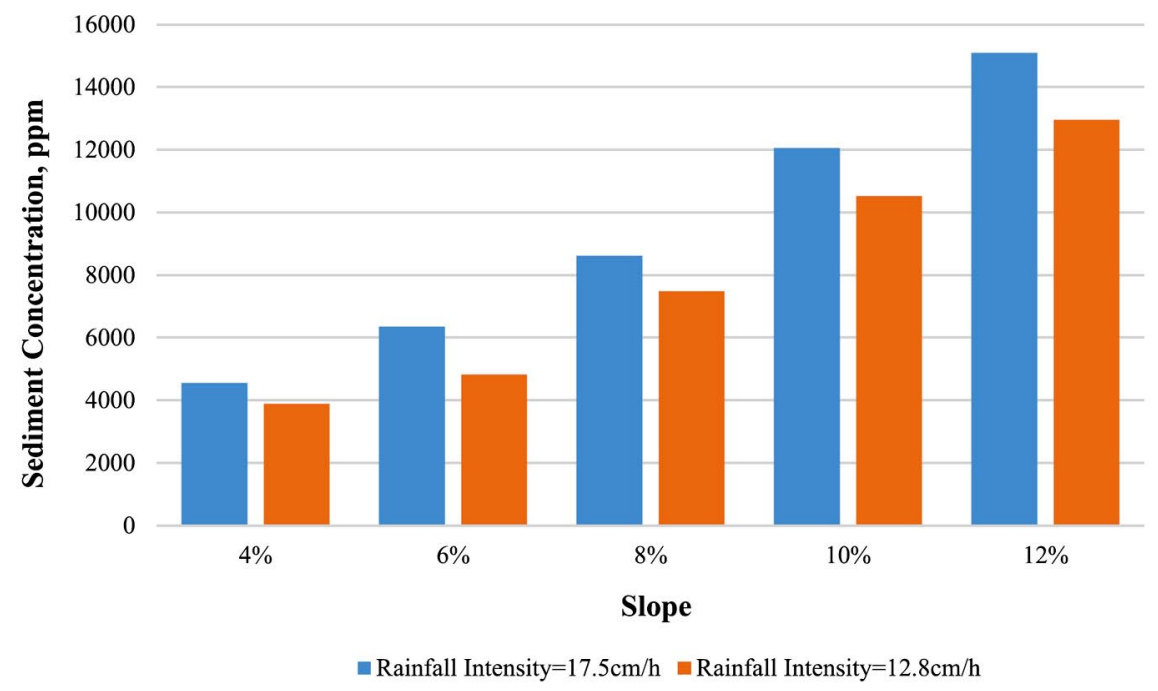

Fig. 9. Observed sediment concentration for cohesion $0.32 \mathrm{~kg} / \mathrm{cm} 2$ and angle of internal friction $10.6^{\circ}$ and different slope and rainfall intensities.

of $0.74 \mathrm{~kg} / \mathrm{cm}^{2}$ and angle of internal friction $16^{\circ}$ (Fig. 10), the pattern of sediment concentration with rainfall intensity and the land slope was similar to the previous cases. However, at slopes of $4 \%$ and $6 \%$, the sediment concentration decreased at a faster rate when rainfall intensity decreased from 17.5 to $12.8 \mathrm{~cm} / \mathrm{h}$. At $6 \%$ land slope, the sediment concentration for $17.5 \mathrm{~cm} / \mathrm{h}$ rainfall intensity was $2,905 \mathrm{ppm}$ while for 12.8 


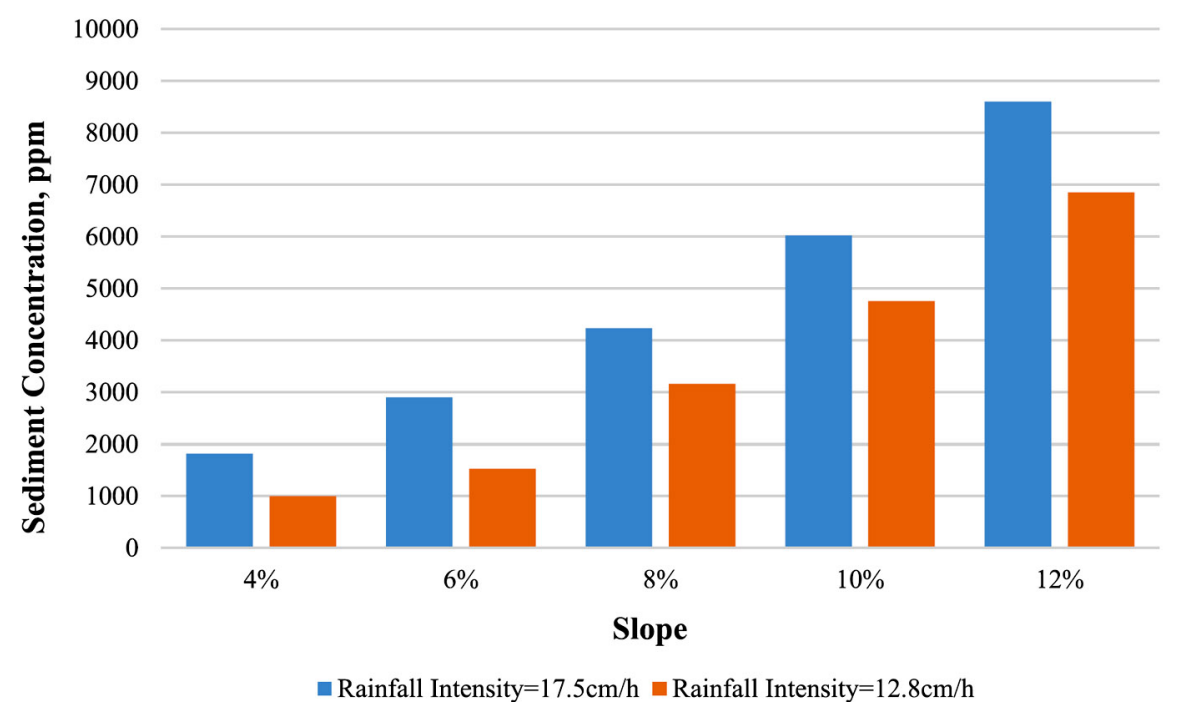

Fig. 10. Observed sediment concentration for cohesion $0.74 \mathrm{~kg} / \mathrm{cm} 2$ and angle of internal friction $16^{\circ}$ and different slope and rainfall intensities.

$\mathrm{cm} / \mathrm{h}$ rainfall intensity it was $1,525 \mathrm{ppm}$ that indicated a reduction of nearly $50 \%$. From the analysis of this trend, it was revealed that with a higher value of cohesion and angle of internal friction at a lower slope, for example, $4 \%$ and $6 \%$, the lower intensity of rainfall was not capable of dislodging and transporting the sediment particles to the outlet and, therefore, the reduction in sediment concentration was significant when rainfall intensity decreased from 17.5 to $12.8 \mathrm{~cm} / \mathrm{h}$.

In general, it was observed that in all cases the sediment concentration values reduction was more predominant with rainfall intensities for soil with $0.74 \mathrm{~kg} / \mathrm{cm}^{2}$ cohesion with a coefficient of internal friction of $16^{\circ}$ when compared with soils with cohesion values of 0.12 and 0.74 $\mathrm{kg} / \mathrm{cm}^{2}$ with a coefficient of internal friction of $6^{\circ}$ and $10.6^{\circ}$, respectively for both the rainfall intensities.

\section{Observed Sediment Concentration for a Particular Value of Rainfall Intensity with Varying Cohesion and Angle of Internal Friction for Selected Land Slopes}

To determine the effect of rainfall intensity on sediment concentration for different values of the shear parameters (cohesion and angle of internal friction) and land slope, a plot between sediment concentration and land slope for different values of cohesion and angle of internal friction 


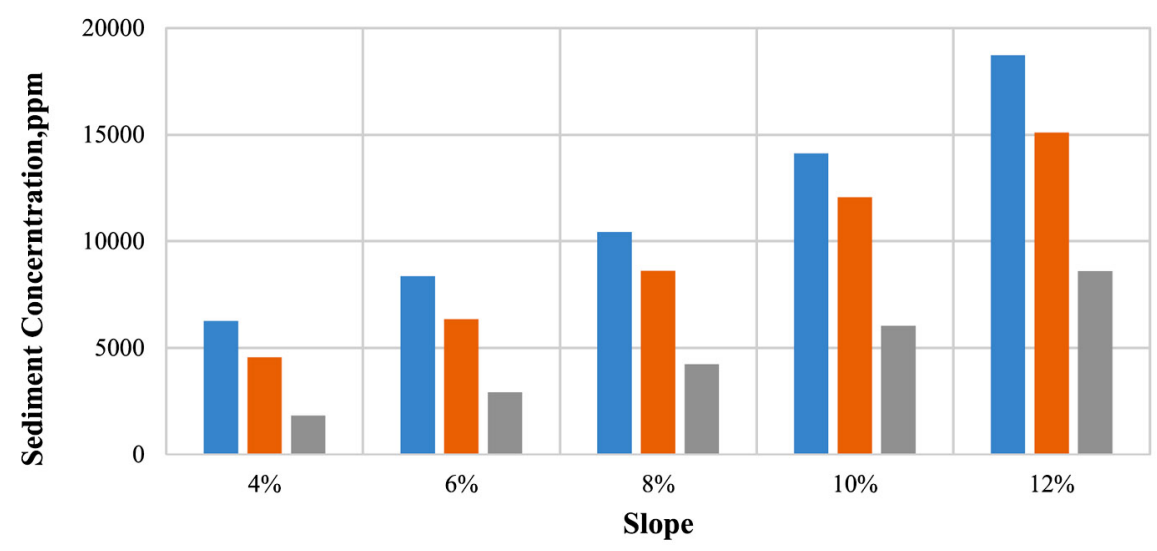

- cohesion $=0.12 \mathrm{~kg} / \mathrm{cm} 2$ and angle of internal friction $=6$ degree a cohesion $=0.32 \mathrm{~kg} / \mathrm{cm} 2$ and angle of internal friction $=10.6$ degree w cohesion $=0.74 \mathrm{~kg} / \mathrm{cm} 2$ and angle of internal friction $=16$ degree

Fig. 11. Observed sediment concentration for different values of shear parameters and land slope at $17.5 \mathrm{~cm} / \mathrm{h}$ rainfall intensity.

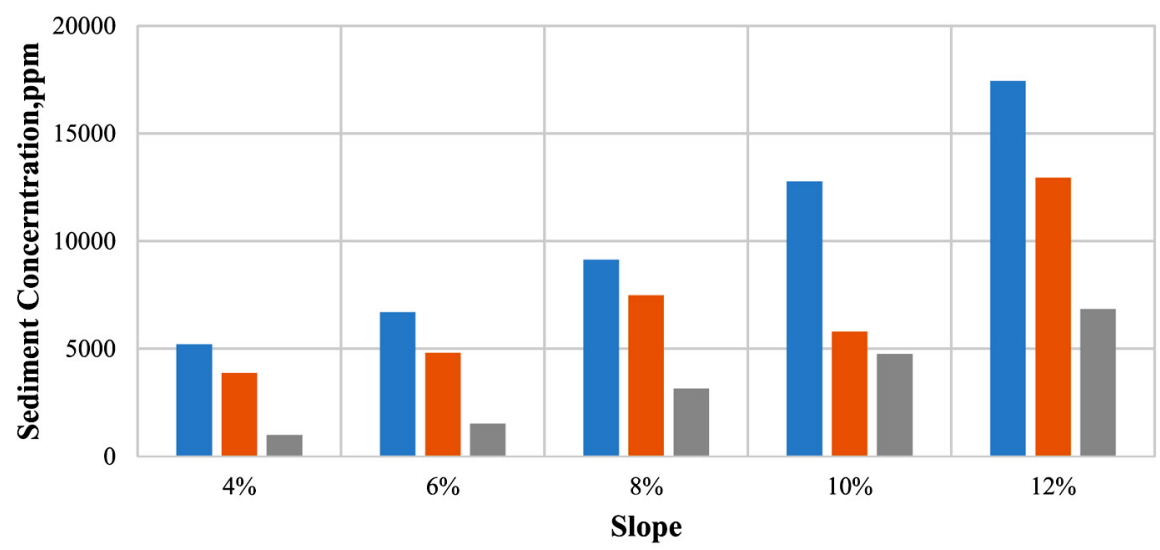

- cohesion $=0.12 \mathrm{~kg} / \mathrm{cm} 2$ and angle of internal friction $=6.0$ degree - cohesion $=0.32 \mathrm{~kg} / \mathrm{cm} 2$ and angle of internal friction $=10.6$ degree w cohesion $=0.74 \mathrm{~kg} / \mathrm{cm} 2$ and angle of internal friction $=16$ degree

Fig. 12. Observed sediment concentration for different values of shear parameters and land slope at $12.8 \mathrm{~cm} / \mathrm{h}$ rainfall intensity.

was drawn as shown in Figs. 11 and 12. From these figures, it was observed that for particular rainfall intensity, the sediment concentration had a decreasing trend for all land slopes for increasing values of cohesion and angle of internal friction as discussed previously. Similarly, for a particular land slope with an increasing value of cohesion and angle of internal friction the sediment concentration had a decreasing trend but had an increasing trend with the land slope for every value of cohesion and angle of internal friction for both of the rainfall intensities. 
The previous analysis indicated that the treatment of soil with soil additives such as guar gum, jute fiber, and their combinations had a positive effect on improving shear parameters of soil including its cohesion and angle of internal friction. The observed values of erosion/sediment outflow concerning shear parameters showed that the sediment outflow had a decreasing trend with improved values of these shear parameters for all selected land slopes and rainfall intensities.

\section{Conclusion}

To produce rainfall to observe sediment outflow for varying soil properties as the result of the treatment of soil with additives, a small size portable rainfall simulation system was developed in the laboratory that was $1 \times 1 \mathrm{~m}^{2}$ in size and operated from a height of $5 \mathrm{~m}$. The simulator was calibrated for its rainfall generation capabilities which mimicked natural rainfall conditions. The simulation system was calibrated to produce rainfall intensities of $12.8 \mathrm{~cm} / \mathrm{h}$ t and $17.5 \mathrm{~cm} / \mathrm{h}$ for water pressures of 0.4 and $0.5 \mathrm{~kg} / \mathrm{cm}^{2}$ which occurred almost uniformly over the entire test plot and gave a uniform coefficient of $>99 \%$. The soil was treated with guar gum at $0.3 \%, 0.5 \%$, and $0.7 \%$ concentration (by weight) and with jute fiber at $0.3 \%, 0.5 \%$, and $0.7 \%$ (by weight), and with guar gum and jute fiber combinations of $0.3 \%$ guar gum and $0.3 \%$ jute; $0.5 \%$ guar gum and $0.5 \%$ jute; and $0.7 \%$ guar gum and $0.7 \%$ jute mixture by weight. The test plots of similar size mounted on a slope adjusting mechanism were also developed for this study. The exhaustive experiments were conducted using different combinations of input variables. For conducting experiments, soil with three different shear parameters was used for different combinations of land slope and rainfall intensities. In this study, it was carried out for 2 rainfall intensities and 5 land slopes. With 3 types of soil, the total number of combinations was $3 \times 2 \times 5=30$ and the experiment for sediment outflow observation was performed 30 times. Every trial was run for $5 \mathrm{~min}$ for rainfall intensities of 12.8 and $17.5 \mathrm{~cm} / \mathrm{h}$. The runoff was generated and $100 \mathrm{~cm}^{3}$ of the representative sample was collected to analyze sediment concentration by following the oven drying method. Based on this study, the following conclusions could be drawn.

The recorded observations revealed that for a particular value of cohesive strength and angle of internal friction of soil which in combination represented its shear strength (cohesion and angle of internal 
friction) had a significant impact on soil erosion for all combinations of land slope and rainfall intensity. It was found that as the value of shear strength of soil increased as a result of the applied treatments, the soil loss rate/sediment outflow rate decreased in all cases. In addition, it was found that for a particular value of cohesion and angle of internal friction, the runoff rate increased with rainfall intensity for every land slope while the sediment concentration and sediment outflow rate increased with rainfall intensity as well as land slope.

In general, it was observed that in all cases the reduction in sediment concentration values was more predominant with rainfall intensities for soil with $0.74 \mathrm{~kg} / \mathrm{cm}^{2}$ cohesion with a coefficient of internal friction of $16^{\circ}$ when compared with soils with cohesion of 0.12 and $0.74 \mathrm{~kg} / \mathrm{cm}^{2}$ with a coefficient of internal friction of $6^{\circ}$ and $10.6^{\circ}$, respectively for both the rainfall intensities. The previous analysis indicated that the treatment of soil with soil additives such as guar gum, jute fiber, and their combinations had a positive effect on improving shear parameters of soil in terms of cohesion and angle of internal friction. The observed values of erosion/ sediment outflow concerning shear parameters showed that the sediment outflow had a decreasing trend with improved values of these shear parameters for all selected land slope and rainfall intensities.

Data Availability All data, models, and code generated or used during the study appear in the published article.

\section{References}

Annandale, G. W. 2006. Reservoir sedimentation. Encyclopedia of hydrological sciences. New York: John Wiley and Sons.

Basu, G., A. N. Roy, P. Sanyal, K. Mitra, L. Mishra, and S. K. Ghosh. 2019. "Bioengineering of river earth embankment using natural fibrebased compositestructured geotextiles." Geotext. Geomembr. 47 (4): 493-501. https://doi. org/10.1016/i.geotexmem.2019.03.002.

Christiansen, J. E. 1942. Irrigation by sprinkling. Berkeley: University of California.

Correia, A. A. S., P. J. Venda Oliveira, and D. G. Custódio. 2015. "Effect of polypropylene fibres on the compressive and tensile strength of a soft soil, artificially stabilised with binders." Geotext. Geomembr. 43 (2): 97-106. https://doi.org/10.1016/j. geotexmem.2014.11.008.

Cruse, R. M., and W. E. Larson. 1977. "Effect of soil shear strength on soil detachment due to raindrop impact 1." Soil Sci. Soc. Am. J. 41 (4): 777-781. https://doi. org/10.2136/sssaj1977.03615995004100040034x. 
Das, D., D. Kaundinya, R. Sarkar, and B. Deb. 2016. "Shear strength improvement of sandy soil using coconut fibre." Int. J. Civ. Eng. Technol. 7 (3): 297-305.

Davidová, T., T. Dostál, V. David, and P. Strauss. 2016. “Determining the protective effect of agricultural cropson the soil erosion process using a field rainfall simulator." Plant Soil Environ. 61 (3): 109-115. https://doi. org/10.17221/903/2014-PSE.

Ellison, W. D. 1948. "Soil detachment by water in erosion processes." Trans. Am. Geophys. Union 29 (4): 499-502. https://doi.org/10.1029/TR029i004p00499.

Ghiban, B., C. A. Safta, M. Ion, C. E. Crângaşu, and M. C. Grecu. 2017. "Structural aspects of silt erosion resistant materials used in hydraulic machines manufacturing." Energy Procedia 112: 75-82. https://doi.org/10.1016/j. egypro.2017.03.1064.

Ghosh, S. K., R. Bhattacharyya, and M. M. Mondal. 2017. "Potential applications of open weave jute geotextile (soil saver) in meeting geotechnical difficulties." Procedia Eng. 200: 200-205. https://doi.org/10.1016/j.proeng.2017.07.029.

Helming, K., S. N. Prasad, and M. J. M. Römkens. 2002. "Soil erosion under different rainfall intensities, surface roughness, and soil water regimes." Catena 46 (2-3): 103-123. https://doi.org/10.1016/S0341-8162(01)00161-8.

Higson, J. L., and M. B. Singer. 2015. "The impact of the streamflow hydrograph on sediment supply from terrace erosion." Geomorphology 248: 475-488. https:// doi.org/10.1016/i.geomorph.2015.07.037.

Issa, O. M., Y. L. Bissonnais, O. Planchon, D. Favis-Mortlock, N. Silvera, and J. Wainwright. 2006. "Soil detachment and transport on field- and laboratory-scale interrill areas: Erosion processes and the sizeselectivity of eroded sediment." Earth Surf. Processes Landforms 31 (8): 929-939. https://doi.org/10.1002/ esp.1303.

Jahangeer, Gupta, P. K., and B. K. Yadav. 2017. "Transient water flow and nitrate movement simulation in partially saturated zone." J. Irrig. Drain. Eng. 143 (12): 04017048. https://doi.org/10.1061/(ASCE)IR.1943-4774.0001238.

Jahangeer, A., and V. Kumar. 2013. "An overview on microbial degradation of petroleum hydrocarbon contaminants." Int. J. Eng. Technol. Res. 1 (8): 34-37.

Kalibová, J., L. Jačka, and J. Petru. 2016. "The effectiveness of jute and coir blankets for erosion control in different field and laboratory conditions." Solid Earth 7 (2): 469-479. https://doi.org/10.5194/se-7-469-2016.

Kondolf, G. M., et al. 2014. "Sustainable sediment management in reservoirs and regulated rivers: Experiences from five continents." Earth's Future 2 (5): 256-280. https://doi.org/10.1002/2013EF000184.

Kumar, V. 2017. "Statistical distribution of rainfall in Uttarakhand, India." Appl. Water Sci. 7 (8): 4765-4776. https://doi.org/10.1007/s13201-017-0586-5.

Lal, R. 2001. "Soil degradation by erosion." Land Degrad. Dev. 12 (6): 519-539. https://doi.org/10.1002/ldr.472.

Lal, R. 2003. "Soil erosion and the global carbon budget." Environ. Int. 29 (4): 437450. https://doi.org/10.1016/S0160-4120(02)00192-7. 
Li, J., C. Tang, D. Wang, X. Pei, and B. Shi. 2014. "Effect of discrete fibre reinforcement on soil tensile strength." J. Rock Mech. Geotech. Eng. 6 (2): 133-137. https://doi. org/10.1016/j.jrmge.2014.01.003.

Li, Z., J. Huang, G. Zeng, X. Nie, W. Ma, W. Yu, W. Guo, and J. Zhang. 2013. "Effect of erosion on productivity in subtropical red soil hilly region: A multi-scale spatiotemporal study by simulated rainfall." PLoS One 8 (10): e77838. https://doi. org/10.1371/journal.pone.0077838.

Liu, H., T. G. Cleveland, and K. H. Wang. 1999. "Laboratory tests of erosion dependence on properties of soils and rainfall1 bays during rainstorms. Storm water runoff from of grassland, and 2000 times that of a forest land upon for certain kinds of practical problems. In tive in transporting soil pa." J. Am. Water Resour. Assoc. 35 (1): 167-176. https://doi.org/10.1111/j.1752-1688.1999. tb05461.x.

Liu, J., Z. Chen, D. P. Kanungo, Z. Song, Y. Bai, Y. Wang, D. Li, and W. Qian. 2019. "Topsoil reinforcement of sandy slope for preventing erosion using water-based polyurethane soil stabilizer." Eng. Geol. 252: 125-135. https://doi.org/10.1016/j. enggeo.2019.03.003.

Martin, A. S. 1940. “Soil erosion.” Aust. Surveyor 8 (1): 45-49. https://doi.org/10.108 0/00050326.1940.10436676.

Mohamadi, M. A., and A. Kavian. 2015. "Effects of rainfall patterns on runoff and soil erosion in field plots." Int. Soil Water Conserv. Res. 3 (4): 273-281. https://doi. org/10.1016/i.iswcr.2015.10.001.

Ranjan, G., R. M. Vasan, and H. D. Charan. 1996. "Probabilistic analysis of randomly distributed fiber-reinforced soil." J. Geotech. Eng. 122 (6): 419-426. https://doi. org/10.1061/(ASCE)07339410(1996)122:6(419).

Rügner, H., et al. 2019. "Particle bound pollutants in rivers: Results from suspended sediment sampling in Globaqua River Basins." Sci. Total Environ. 647: 645-652. https://doi.org/10.1016/j.scitotenv.2018.08.027.

Sharma, G., S. Sharma, A. Kumar, A. H. Al-Muhtaseb, M. Naushad, A. A. Ghfar, G. T. Mola, and F. J. Stadler. 2018. "Guar gum and its composites as potential materials for diverse applications: A review." Carbohydr. Polym. 199: 534-545. https://doi. org/10.1016/j.carbpol.2018.07.053.

Thapa, B. S., B. Thapa, and O. G. Dahlhaug. 2012. "Empirical modelling of sediment erosion in Francis turbines.” Energy 41 (1): 386-391. https://doi.org/10.1016/j. energy.2012.02.066.

Vaezi, A. R., M. Ahmadi, and A. Cerdà. 2017. “Contribution of raindrop impact to the change of soil physical properties and water erosion under semiarid rainfalls." Sci. Total Environ. 583: 382-392. https://doi.org/10.1016/j. scitotenv.2017.01.078.

WHO (World Health Organisation). 2008. Vol. 1 of WHO guidelines for drinking-water quality. 3rd ed. Geneva: WHO.

Ziadat, F. M., and A. Y. Taimeh. 2013. "Effect of rainfall intensity, slope, land use and antecedent soil moisture on soil erosion in an arid environment." Land Degrad. Dev. 24 (6): 582-590. https://doi.org/10.1002/ldr.2239. 